
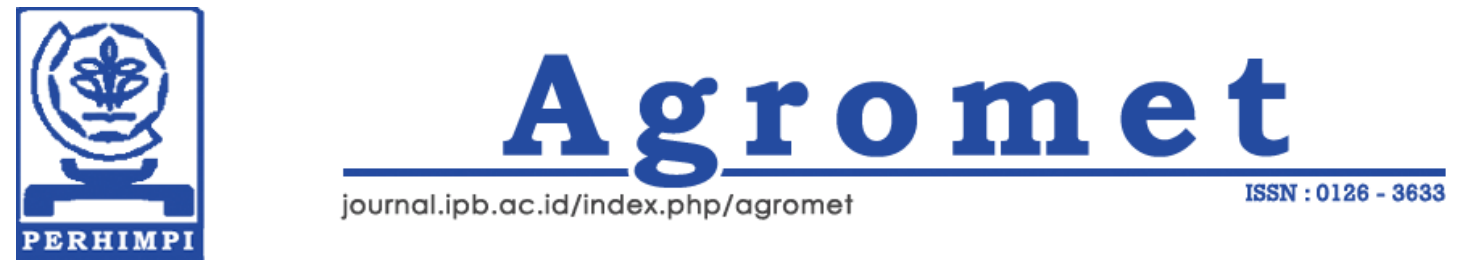

PENDUGAAN PERTUMBUHAN DALAM MODEL SIMULASI KEDELAI ( GL YCINE MAX (L.) MERRILL) DENGAN PENDEKATAN NERACA ENERGI

\author{
Model Simulation of Soybean (Glycine Max (L.) Merril) Growth by Energy Balance Approach
}

\title{
Fajar Syofwan, dan Handoko*
}

Departemen Geofisika dan Meteorologi, Gedung FMIPA JIn. Meranti Wing 19 Lv 4, Kampus IPB Darmaga, Bogor 16680

\section{ARTICLE INFO}

\section{Article history:}

Received 2 April 2018

Received in revised from 1 June 2018

Accepted 11 June 2018

doi: 10.29244/j.agromet.32.1.31-41

\section{Keywords: \\ Bowen ratio \\ Crop models \\ Crop physiology \\ Intercepted radiation \\ Solar radiation}

\begin{abstract}
A B S T R A C T
Intercepted solar radiation by leaf will influence energy balance in plant. The energy balance in leaf is a complex process, which results in biomass growth. Here, we modeled leaf energy balance to estimate dry matter growth in soybean. In the field, we measured intercepted radiation in canopy (1 meter above surface) with two treatments: soybean with $50 \%$ shading (N50\%M0) and no-shading (N0\%M0) twice a week. Then we sampled a biomass with destructive technique every week in each treatment. Our results showed that the intercepted radiation in no-shading treatment was higher $\left(400 \mathrm{~J} / \mathrm{m}^{2}\right)$ than those in shading one $\left(250 \mathrm{~J} / \mathrm{m}^{2}\right)$. The results were consistence with the high biomass growth at 12 weeks after planting, which observed in no-shading treatment. Then we validated our model by 1:1 plot test. Our finding revealed that no-shading treatment showed a good agreement with the observed biomass (closed to 1:1 plot), whereas the shading treatment tended to predict under estimate of biomass.
\end{abstract}

\section{PENDAHULUAN}

Model simulasi tanaman merupakan hubungan matematika terhadap berbagai proses dari pertumbuhan tanaman, perkembangan tanaman, dan respon tanaman terhadap faktor lingkungan (Craufurd et al., 2013; Hammer et al., 2016; Rauff dan Bello, 2015; Singels, 2013). Model simulasi tersebut banyak berguna bagi kegiatan pertanian, seperti untuk memahami proses pertumbuhan biomassa tanaman (Tilly et al., 2014; Van Roekel dan Purcell, 2014), dan manajemen budidaya tanaman (García-Vila dan Fereres, 2012; Kloss et al., 2012).

Secara umum, model simulasi tanaman disusun berdasarkan kondisi faktor iklim, kemudian divalidasi menggunakan data biomassa tanaman hasil observasi di lapang. Suhu dan radiasi matahari merupakan faktor iklim yang paling berpengaruh terhadap perkembangan dan pertumbuhan tanaman (Dong et al., 2012; Hatfield dan Prueger, 2015). Parameter iklim yang digunakan sebagai pendekatan utama dalam membangun model simulasi tanaman kedelai pada penelitian ini adalah radiasi matahari.

Radiasi matahari yang sampai di bumi akan dimanfaatkan oleh tanaman untuk pertumbuhan. Tanaman yang terpapar radiasi matahari akan menyerap/mengintersepsi radiasi matahari melalui organ daun tanaman. Radiasi hasil intersepsi dikonversi menjadi energi dalam neraca energi. Penelitian ini menggunakan konsep neraca energi pada daun tanaman (Gutschick, 2016; Ye et al., 2013), yang terdiri dari sensible heat flux $(\mathrm{H})$ dan latent heat flux $\left(\mathrm{H}_{\mathrm{L}}\right)$. Kedua energi tersebut digunakan untuk memanaskan udara dan penguapan air oleh tanaman. Penelitian ini bertujuan untuk membuat model simulasi tanaman kedelai dengan pendekatan neraca energi pada daun tanaman dan melakukan validasi model simulasi tanaman untuk mendapatkan hasil pertumbuhan biomassa yang sesuai.

\footnotetext{
*corresponding author: handoko@ipb.ac.id
} 


\section{METODE PENELITIAN}

\section{Waktu dan Tempat Penelitian}

Penelitian lapang dilaksanakan selama tiga bulan pada periode 15 Oktober 2016 hingga 15 Januari 2017 berlokasi di Cilubang Mekar, Situ Gede, Bogor Barat, Jawa Barat. Tanaman kedelai ditanam pada bedengan seluas $1 \times 7 \mathrm{~m}^{2}$ dengan jarak tanam $30 \mathrm{~cm}$ (kerapatan 9 tanaman $/ \mathrm{m}^{2}$ ). Terdapat dua perlakuan yang diuji di lapangan dengan penerimaan radiasi surya berbeda, yaitu: (1) tanpa naungan (NO\%M0) seperti pada Gambar
$1 \mathrm{a}$, dan (2) dengan naungan 50\% (N50\%M0) seperti pada Gambar $1 b$.

\section{Data dan Alat}

Beberapa alat ukur digunakan dalam penelitian ini untuk pengukuran faktor-faktor lingkungan. Radiasi surya diukur dengan solarimeter, sedangkan suhu udara diamati dengan sensor DHT22. Pengukuran dilakukan pada dua ketinggian yang berbeda, yaitu (a) ketinggian $1 \mathrm{~m}$ (kanopi) dari permukaan tanah, dan (b) ketinggian $1.1 \mathrm{~m}$ (lingkungan) dari permukaan tanah.
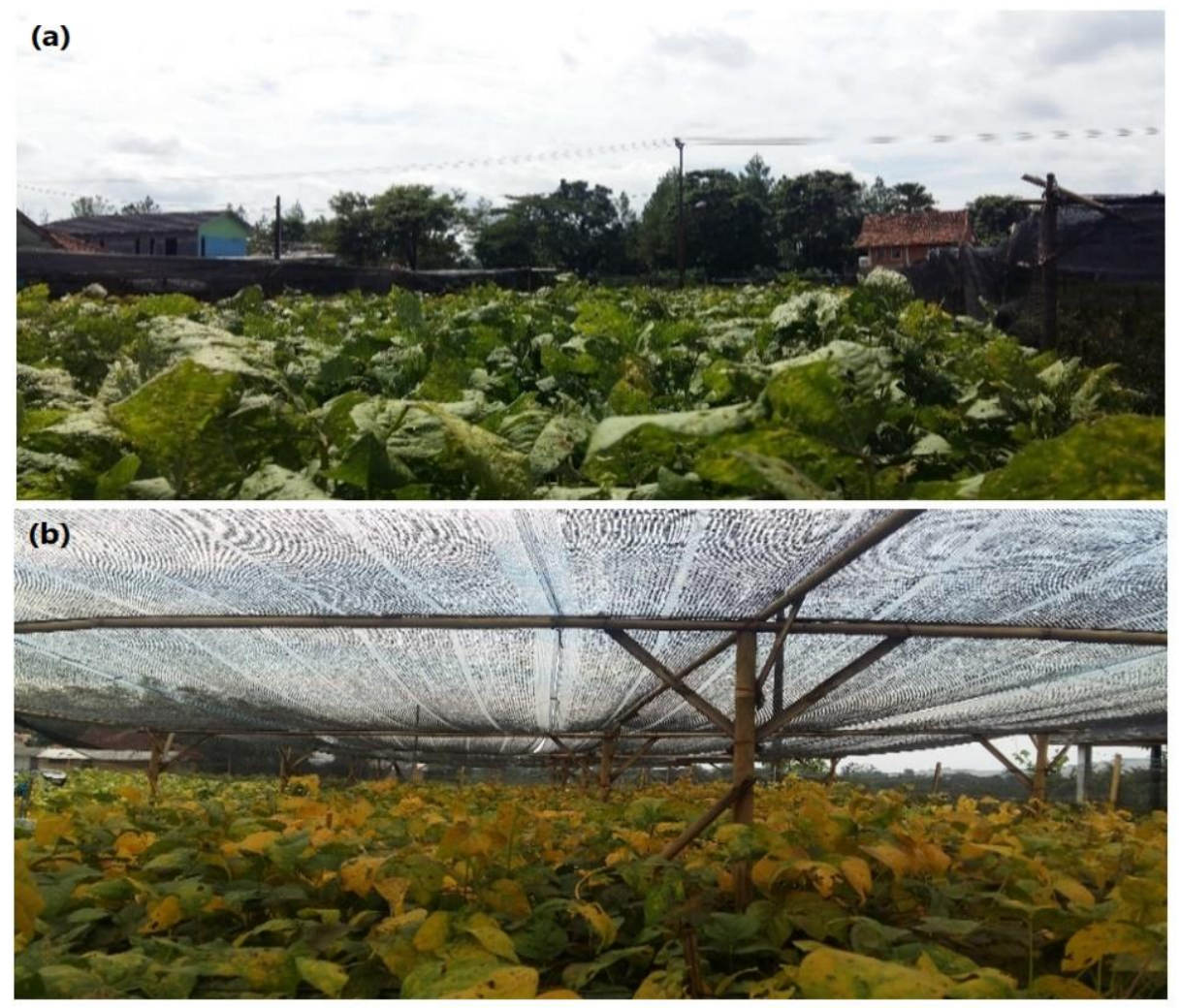

Gambar 1 Tanaman kedelai dua perlakuan, yaitu: (a) N0\%M0 atau tanpa naungan, dan (b) $\mathrm{N} 50 \% \mathrm{M0}$ atau ternaungi $50 \%$.

Dari pengukuran suhu udara, akan diperoleh nilai suhu udara maksimum dan minimum yang digunakan untuk perhitungan nilai kelembaban relatif daun/kanopi dan lingkungan. Data pengukuran solarimeter digunakan untuk menduga nilai intersepsi radiasi oleh tajuk tanaman. Pengukuran tersebut tidak dilakukan secara kontinu setiap hari, melainkan dilakukan sebanyak dua kali dalam seminggu baik secara manual atau otomatis menggunakan logger untuk perekaman data setiap lima menit. Data tersebut kemudian dikombinasikan dengan data iklim harian hasil pengukuran automatic weather station (AWS) dan data parameter fisik tanaman kedelai untuk membangun model simulasi tanaman kedelai. Selain pengukuran tersebut, data biomassa tanaman diambil dengan metode destruktif yang dilakukan setiap minggu.

\section{Analisis Neraca Energi pada Daun Tanaman}

Pertumbuhan tanaman ditentukan oleh dua prinsip pokok yaitu partisi produk fotosintesis ke organ tumbuhan dan laju respirasi dari masing-masing organ tersebut (Chuine et al., 2013). Model pertumbuhan tanaman berfokus pada produksi berat kering sebagai hasil yang dapat dilihat dari suatu proses aliran energi. Pertumbuhan tanaman ditentukan oleh dua hal, yaitu: partisi produk fotosintesis ke organ utama (Boote et al., 
2013; Poorter et al., 2015), dan laju respirasi dari masingmasing organ tersebut (Boote et al., 2013; Song et al., 2013). Rumus matematik dari konsep neraca energi pada tanaman (Arya, 1988) tersaji pada Persamaan (1).

$$
\text { Rnet }=H+H_{L}+H_{G}+\Delta H_{S}
$$

dimana Rnet adalah radiasi Netto (MJ $\mathrm{m}^{-2}$ hari $^{-1}$ ), $H_{L}$ energi untuk evapotranspirasi (latent heat flux) (MJ $\mathrm{m}^{-2}$ hari-1 $\left.^{-1}\right), H$ perpindahan panas terasa (sensible heat flux) $\left(\mathrm{MJ} \mathrm{m} \mathrm{m}^{-2}\right.$ hari $\left.^{-1}\right), H_{G}$ perpindahan panas tanah (soil heat flux)(MJ $\mathrm{m}^{-2}$ hari-1), $\Delta H_{S}$ simpanan energi (penyimpanan panas fisik dan penyimpanan panas biokimia sebagai hasil fotosintesis dan pertukaran karbon dioksida) (MJ $\mathrm{m}^{-2}$ hari $^{-1}$ ).

Tanaman mengelola energi dari paparan sinar matahari yang diserap, sehingga nilai radiasi netto pada neraca energi oleh daun tanaman diasumsikan sama dengan nilai intersepsi radiasi. Nilai panas tanah diasumsikan bernilai 0 dalam satu hari. Besaran energi panas tanah tidak berbeda antara siang dan malam, sehingga panas tanah bernilai negatif selama malam hari dan bernilai positif pada siang hari (Arya, 1988).

Nilai $\Delta H s$ digunakan untuk menentukan estimasi biomassa dan panas kapasitas pohon dan observasi suhu udara di dalam kanopi (Arya, 1988). Jadi, nilai $\Delta H_{S}$ sama dengan laju pertumbuhan biomassa dan dapat diduga menggunakan Persamaan (2)-(4).

$$
\begin{aligned}
& \Delta H_{S}=d w \\
& \text { Int }=H+H_{L}+0+d w \\
& \text { dint }=\text { Int }-d w
\end{aligned}
$$

dimana $d w$ pertumbuhann biomassa $\left(\mathrm{MJ} \mathrm{m}^{-2}\right.$ hari $\left.^{-1}\right)$, dint perubahan nilai intersepsi radiasi ( $\mathrm{MJ} \mathrm{m}^{-2}$ hari- $^{-1}$ ). Formula untuk menggambarkan nilai neraca energi oleh daun tanaman dilakukan menggunakan Persamaan (5). Menurut Foken (2008) nilai 6 (rasio bowen) dapat diperoleh dengan Persamaan (6).

$$
\begin{aligned}
& \operatorname{din} t=H+H_{L} \\
& \beta=\gamma \frac{\delta_{T}}{\delta_{e}}=\beta=\frac{H}{H_{L}}
\end{aligned}
$$

dimana $\delta_{T}$ perubahan suhu terhadap ketinggian $\left({ }^{\circ} \mathrm{C}\right), \delta_{e}$ perubahan tekanan uap air terhadap ketinggian $(\mathrm{Pa}), \gamma$ konstanta psychrometric $\left(\mathrm{Pa}{ }^{\circ} \mathrm{C}^{-1}\right)$. Konstanta psychrometric dapat ditentukan menggunakan tabel sebagai fungsi dari ketinggian ( $\mathrm{z}$ ), atau dapat pula dihitung berdasarkan rumus pada Persamaan (7) dan (8) (Allen et al., 1998).

$$
\gamma=\frac{c_{p} P}{\varepsilon \lambda}=0.665 \times 10^{-3} P
$$

$$
P=101.3\left(\frac{293-0.0065 z}{293}\right)^{5.26}
$$

dimana $P$ tekanan atmosfer $(\mathrm{Pa}), \lambda$ laten heat of vaporization $2.45\left(\mathrm{MJ} \mathrm{Kg}^{-1}\right), c_{p}$ konstanta pemanasan spesifik pada tekanan konstan $1013\left(\mathrm{~J} \mathrm{Kg}^{-1}{ }^{\circ} \mathrm{C}^{-1}\right), \varepsilon$ perbandingan berat molekul uap air terhadap berat molekul udara kering 0.62 .

\section{Laju Pertumbuhan Biomassa}

Laju pertumbuhan biomassa (MJ $\mathrm{m}^{-2}$ hari ${ }^{-1}$ ) didapat dari beberapa proses perhitungan menggunakan energi intersepsi radiasi yang telah di koreksi oleh LAI (Leaf Area Index) dan koefisien pemadaman (0.5) dari awal penanaman sampai dengan panen untuk mendapatkan nilai intersepsi radiasi yang digunakan untuk pertumbuhan biomassa. Efisiensi adalah persentase energi radiasi matahari yang dibutuhkan tanaman untuk diubah ke bahan organik melewati fotosintesis. Meskipun tanaman banyak terpapar radiasi matahari, hanya sekitar $1 \%$ dari paparan radiasi matahari tersebut yang digunakan dalam fotosintesis (Kaufman dan Marsh, 2013). Pendugaan laju biomassa potensial menggunakan Persamaan (9).

$$
d w_{\text {potensial }}=\operatorname{Int}_{L A I} * 1 \%
$$

dimana $d w_{\text {potensial }}$ laju pertumbuhan biomassa potensial (MJ $\mathrm{m}^{-2}$ hari $^{-1}$ ), Int Lai $_{\text {La }}$ intersepsi radiasi matahari yang dikoreksi dengan LAI (MJ $\mathrm{m}^{-2}$ hari $\left.{ }^{-1}\right)$.

Pendugaan nilai $d w_{a k t u a l}$ didekati dengan nilai respirasi sebagai faktor koreksi terhadap $w_{\text {potensial }}$ yaitu sebagai kehilangan alokasi biomassa aktual pada tanaman. Laju pertumbuhan biomassa aktual (Handoko, 1994) dapat diduga menggunakan Persamaan (10) dan (11).

$$
\begin{aligned}
& Q_{10}=2^{(T-20) / 10} \\
& d w_{a k t(h)}=w_{p o t}-k m * w_{a k t(h-1)} * Q_{10}
\end{aligned}
$$

dimana $d w_{\text {aktual }}$ laju pertumbuhan biomassa aktual (MJ $\mathrm{m}^{-2}$ hari $\left.^{-1}\right), w_{\text {aktual }}$ biomassa aktual (MJ $\mathrm{m}^{-2}$ hari- $\left.{ }^{-1}\right), Q_{10}$ faktor koreksi respirasi, $T$ suhu lingkungan $\left({ }^{\circ} \mathrm{C}\right), \mathrm{km}$ koefisien respirasi pemeliharaan (0.14 sampai dengan 0.015) (Sheehy dan Mitchell, 2013). Setelah nilai $d w_{\text {aktual }}$ diketahui, kemudian diubah ke nilai $W_{\text {aktual }}$ untuk melihat pertumbuhan biomassa setiap hari setelah tanam (HST). $W_{\text {aktual }}$ yang didapat masih berada dalam satuan energi yaitu $\mathrm{MJ} \mathrm{m}^{-2}$. Hasil $W_{\text {aktual }}$ dikonversi ke dalam bentuk satuan berat menggunakan Persamaan (12) dan (13).

$$
W_{a k}\left(M J \text { tanaman }^{-1}\right)=\frac{W_{a k}\left(M^{-2} m^{-2}\right)}{\text { kerapatan tanmn }}
$$




$$
W_{a k}\left(\text { tanaman }^{-1}\right)=\frac{W_{a k}(M J)}{7 \times 10^{-3}\left(M_{J g}^{-1}\right)}
$$

dimana kerapatan tanaman sebesar 9 tanaman $\mathrm{m}^{-2}$.

\section{Validasi Model}

Validasi dilakukan dengan uji plot 1:1 (Ghasemi dan Zahediasl, 2012) antara data hasil prediksi model pertumbuhan biomassa dan data observasi. Jika data hasil model dan data observasi tersebut makin berimpit pada plot 1:1 berarti data hasil model dapat memprediksi pertumbuhan biomassa tanaman.

\section{HASIL DAN PEMBAHASAN}

\section{Profil Energi Tanaman}

Nilai Bowen ratio ( $B$ ) menggambarkan ratio energi yang digunakan untuk pemanasan udara (sensible heat, $H$ ) dengan energi digunakan untuk penguapan (latent heat, $H_{L}$ ). Suhu $(\mathrm{T})$ lingkungan dan daun pada pukul 23:58 WIB sampai dengan 08:13 WIB tanggal 5 Januari 2017 (Gambar 2a) mengalami perubahan kecil pada rentang 20 hingga $25^{\circ} \mathrm{C}$, dengan nilai $\mathrm{RH}$ (kelembaban relatif) stabil pada $99 \%$. Sedangkan pada pukul 08:43 sampai dengan 10:28 WIB, T lingkungan dan daun mengalami peningkatan menjadi 25 hingga $32^{\circ} \mathrm{C}$. Hal ini menjelaskan ketika $\mathrm{T}$ mengalami peningkatan maka laju pemuaian volume udara lebih besar daripada laju penguapan air, sehingga RH mengalami penurunan.

Perubahan nilai perbedaan suhu ( $\delta \mathrm{T})$ dan perbedaan tekanan uap air ( $\delta$ e) terlihat pada Gambar $2 b$ menyebabkan nilai $\beta$ mengalami perubahan signifikan pada jam 00:43, 03:28, dan 10:28 WIB yang dipengaruhi oleh nilai T dan $\mathrm{RH}$. Perubahan ini terjadi akibat adveksi yaitu perubahan panas secara horizontal yang mengakibatkan perubahan fisik di udara sehingga menyebabkan nilai $\mathrm{T}$ dan $\mathrm{RH}$ di lahan mengalami perubahan. Pada pukul 10:28 aktivitas adveksi (Gambar 2a) menyebabkan $\mathrm{RH}$ yang terukur pada lingkungan menurun secara signifikan dari nilai $98 \%$ hingga $79 \%$. Sedangkan, RH pada daun terukur stabil pada kisaran 85\%-95\%. Perbedaan penurunan kelembaban relatif ini mengakibat nilai $\beta$ (Gambar 2c) mengalami penurunan yang sangat signifikan pada pukul 10:28 WIB.

Perbedaan $\mathrm{RH}$ lingkungan dan daun perlakuan N0\%M0 terukur pada pukul 14:48 hingga 17:18 WIB tanggal 29 Desember 2016 (Gambar 3a) mencapai 10\% dengan penurunan $\mathrm{T}$ daun dan lingkungan yang terukur stabil pada kisaran $25^{\circ} \mathrm{C}-31^{\circ} \mathrm{C}$. Hal ini menunjukkan bahwa pada pukul 14:48 hingga 17:18 WIB terjadi adveksi sehingga nilai $\mathrm{RH}$ lingkungan mengalami penurunan yang lebih besar dibandingkan pada $\mathrm{RH}$

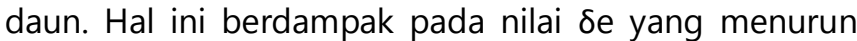
secara signifikan dari 300 menjadi 50 Pa (Gambar 3b), dan nilai $\beta$ meningkat secara signifikan dari rentang 0.02 hingga 0.4 (Gambar 3c) pada pukul 14:48 hingga 17:18 WIB.

Laju penguapan air tanaman pada pukul 10:13 sampai dengan 11:18 WIB mengalami kenaikan yang cukup signifikan tergambar pada nilai $T$ lingkungan dan daun mengalami peningkatan ditandai dengan penurunan $\mathrm{RH}$ lingkungan dan daun pada rentang nilai 60\%-80\% tanggal 30 Desember 2016 (Gambar 3a). Nilai $\beta$ pada jam 14:23 WIB tanggal 29 Desember 2016 mulai mengalami peningkatan yang cukup tajam (Gambar 3c) disebabkan oleh nilai $\delta$ yang stabil pada rentang 220$300 \mathrm{~Pa}$, sedangkan nilai $\delta \mathrm{T}$ mengalami perubahan yang signifikan pada rentang nilai $0.02^{\circ} \mathrm{C}-0.9^{\circ} \mathrm{C}$ (Gambar $3 \mathrm{~b}$ ).

Pola sensible heat flux $(\mathrm{H})$ mengikuti pola latent heat flux $\left(\mathrm{H}_{\mathrm{L}}\right)$, karena pemanasan udara dan penguapan air oleh daun tanaman saling berhubungan satu sama yang lain. Bila terjadi evaporasi, maka sistem yang berevaporasi mengalami pengurangan energi, sedangkan aliran energi akan bersifat positif. Perlakuan N0\%M0 mempunyai fluktuasi energi yang terukur sensor untuk setiap hari.

Puncak energi radiasi yang terintersepsi pada tanggal 29 Desember 2016 (Gambar 4a) tercatat pada pukul 12:05 WIB berada pada nilai $580 \mathrm{~J} / \mathrm{m}^{2}$, dan pada tanggal 30 Desember 2016 tercatat pada pukul 12:10 WIB berada pada nilai $421 \mathrm{~J} / \mathrm{m}^{2}$ terukur dalam resolusi 5 menitan. Energi yang terintersepsi akan terkonversi ke energi $H$ atau $H_{L}$ yang bergantung pada nilai $\beta$, dan dimanfaatkan untuk memanaskan udara dan melakukan penguapan air dari stomata daun ke lingkungan.

Gambar 3c menunjukkan bahwa nilai $\beta$ relatif besar pada jam 09:48 WIB tanggal 29 Desember 2016. Nilai $\beta$ akan relatif besar pada saat pertambahan energi radiasi yang diserap oleh daun. Hal ini menjelaskan pada saat tersebut kemampuan udara untuk menerima panas terasa $(\mathrm{H})$ masih cukup besar yang dikeluarkan oleh daun tanaman sebagai respon terhadap lingkungannya (Gambar 4a) sehingga udara terasa lembab. Proporsi energi yang terkonversi menjadi $\mathrm{H}$ lebih besar pada pukul 09:48 WIB berada pada nilai $112 \mathrm{~J} / \mathrm{m}^{2}$. 

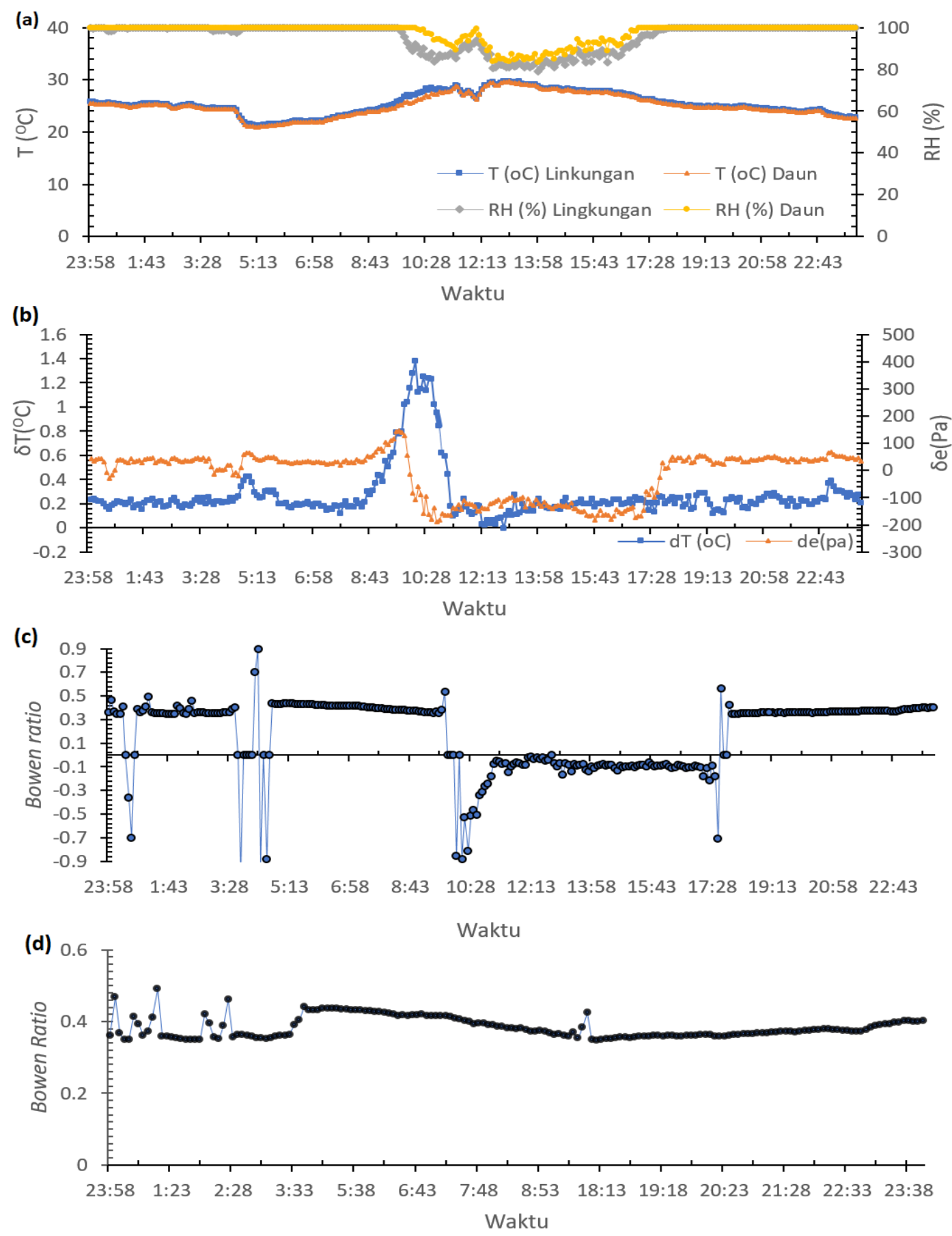

Gambar 2 Variasi diurnal: (a) nilai T dan RH, (b) nilai $\delta \mathrm{T}$ dan $\delta e$ pada ketinggian yang berbeda, (c) nilai Bowen ratio, (d) nilai Bowen ratio telah dikoreksi dengan adveksi, pada tanggal 5 Januari 2017 untuk tanaman perlakuan N50\%M0 atau ternaungi 50\%.

Proporsi energi yang terkonversi menjadi $H_{\llcorner}$ lebih banyak pada saat nilai $\beta$ menurun meskipun fluktuasinya cukup besar (Gambar 3c). Hal ini menjelaskan ketika nilai $\beta$ cendurung menurun, proporsi energi yang terkonversi untuk melakukan penguapan air $\left(\mathrm{H}_{\mathrm{L}}\right)$ oleh daun tanaman lebih besar dibandingkan dengan panas terasa $(\mathrm{H})$. Terlihat bahwa pada tanggal 29
Desember dan 30 Desember 2016 aktivitas energi $H_{L}$ untuk menguapkan air oleh daun tanaman lebih besar pada pukul 14:10 hingga 17:30 WIB untuk kedua hari tersebut. Proporsi energi $H_{L}$ untuk menguapkan udara melalui stomata daun tanaman berada pada rentang nilai 39-422 J/m² untuk tanggal 29 Desember 2016 dan rentang nilai $29-122 \mathrm{~J} / \mathrm{m}^{2}$ untuk tanggal 30 Desember 2017. 

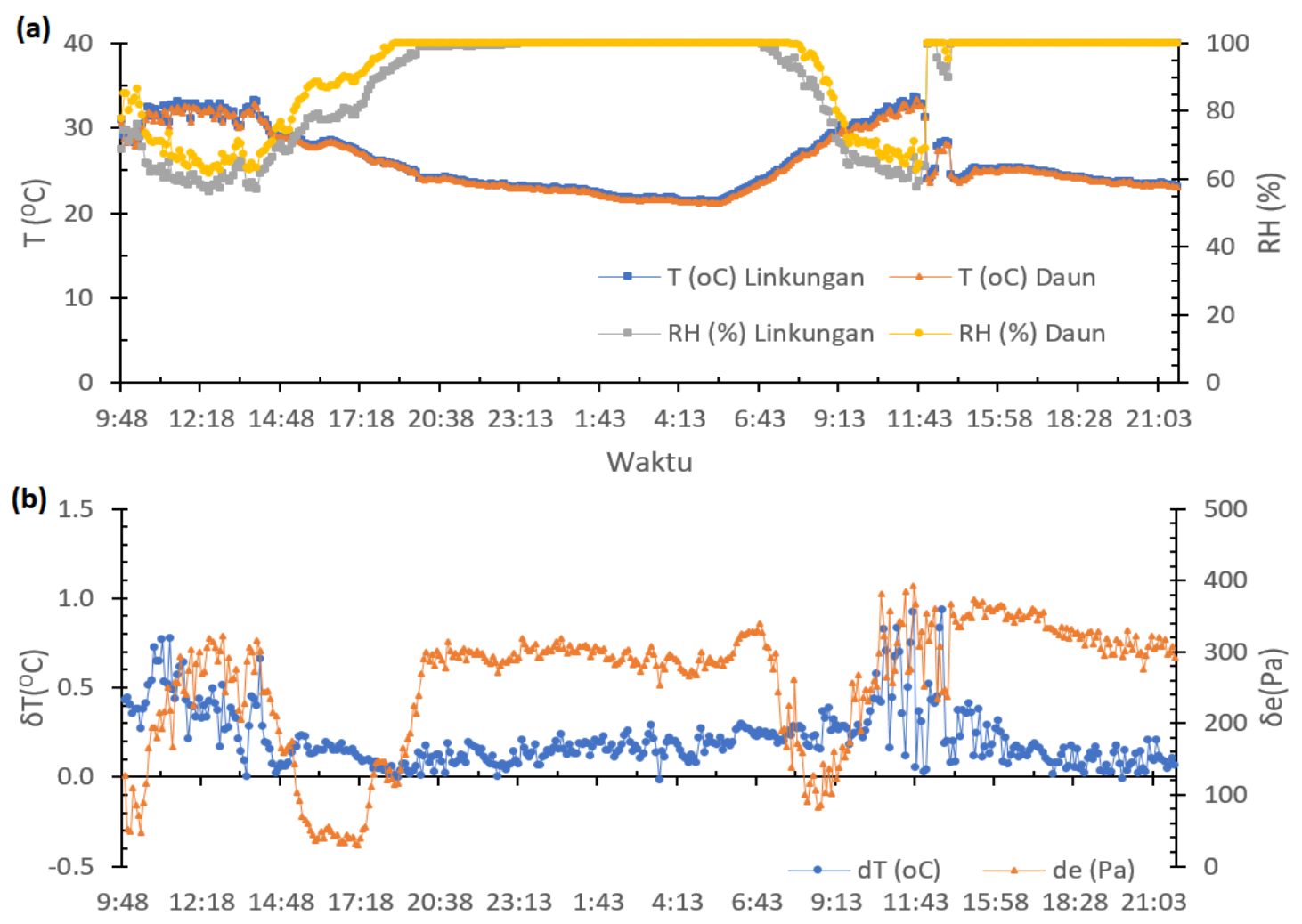

Waktu

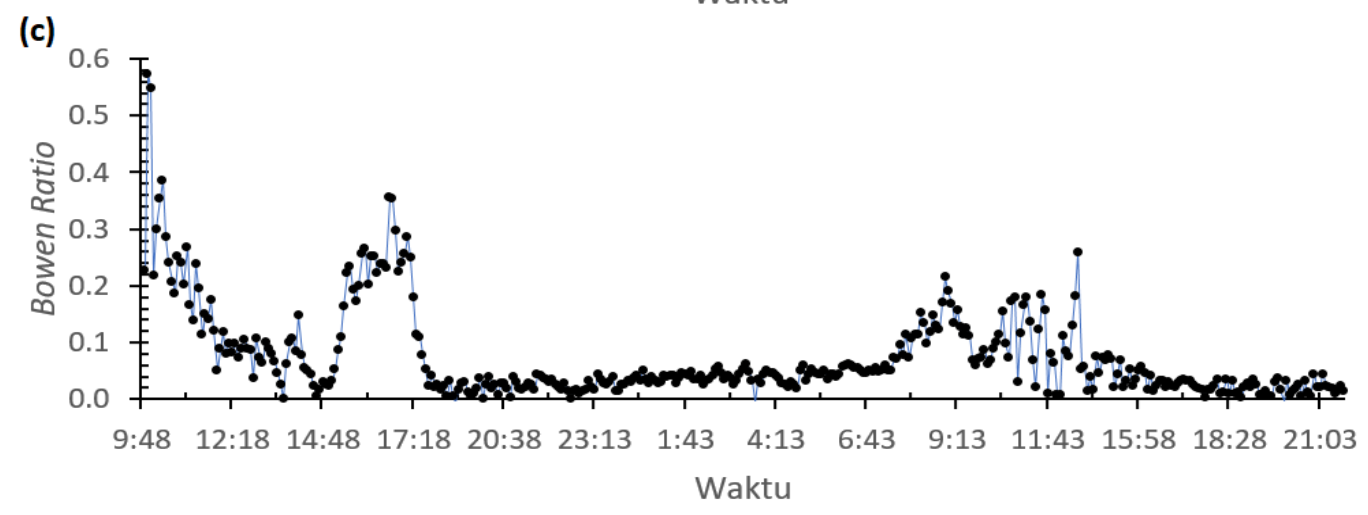

Gambar 3 Variasi nilai harian: (a) T dan RH, (b) $\delta \mathrm{T}$ dan $\delta e ~ p a d a ~ k e t i n g g i a n$ yang berbeda, dan (c) Bowen ratio pada tanggal 29-30 Desember 2016 pada tanaman perlakuan N0\%M0 atau tanpa naungan.

Energi radiasi tidak terintersepsi oleh daun tanaman pada pukul 12:40 WIB pada tanggal 30 Desember 2016 selama beberapa menit. Hal ini disebabkan oleh radiasi matahari tidak dapat menyinari lahan tanaman kedelai karena tertutupi awan. Pada pukul 12:40 WIB tidak ada aktivitas $\mathrm{H}_{\mathrm{L}}$ dan $\mathrm{H}$ yang tergambarkan pada pukul tersebut, sehingga keadaan dilahan observasi terasa sejuk untuk selang beberapa menit.

Nilai $\mathrm{H}$ dan $\mathrm{H}_{\mathrm{L}}$ mengalami over estimated atau melampaui nilai intersepsi radiasi matahari (Gambar 5b). Hal ini disebabkan oleh aktivitas adveksi yang terjadi dan terukur oleh sensor sehingga menganggu nilai suhu dan kelembaban di lahan. Perlakuan N50\%M0 pada Gambar 5 menunjukkan fluktuasi energi yang terukur sensor untuk setiap hari. Puncak energi radiasi yang terintersepsi pada tanggal 4 Januari 2017 (Gambar 5a) tercatat pada pukul 10:10 WIB sebesar $128 \mathrm{~J} / \mathrm{m}^{2}$, dan pada tanggal 5 Januari 2017 (Gambar 5b) tercatat pada pukul 14:10 WIB pada kisaran $235 \mathrm{~J} / \mathrm{m}^{2}$ yang terukur dalam resolusi 5 menitan.

Nilai $\beta$ maksimum yang terukur dinilai 0.57 pada tanggal 5 Januari 2017 lebih besar dibandingkan dengan rata-rata nilai $\beta$ tanggal 4 Januari 2017 (0.42). Hal ini menjelaskan pada tanggal 5 Januari 2017 lebih banyak energi yang dikonversi menjadi $\mathrm{H}$ untuk memanaskan 
udara sebagai respon tanaman terhadap lingkungan sekitar. Pada pukul 09:20 WIB (Gambar 5b) tercatat bahwa energi untuk memanaskan udara $(\mathrm{H})$ berada pada nilai $40 \mathrm{~J} / \mathrm{m}^{2}$.

\section{(a)}
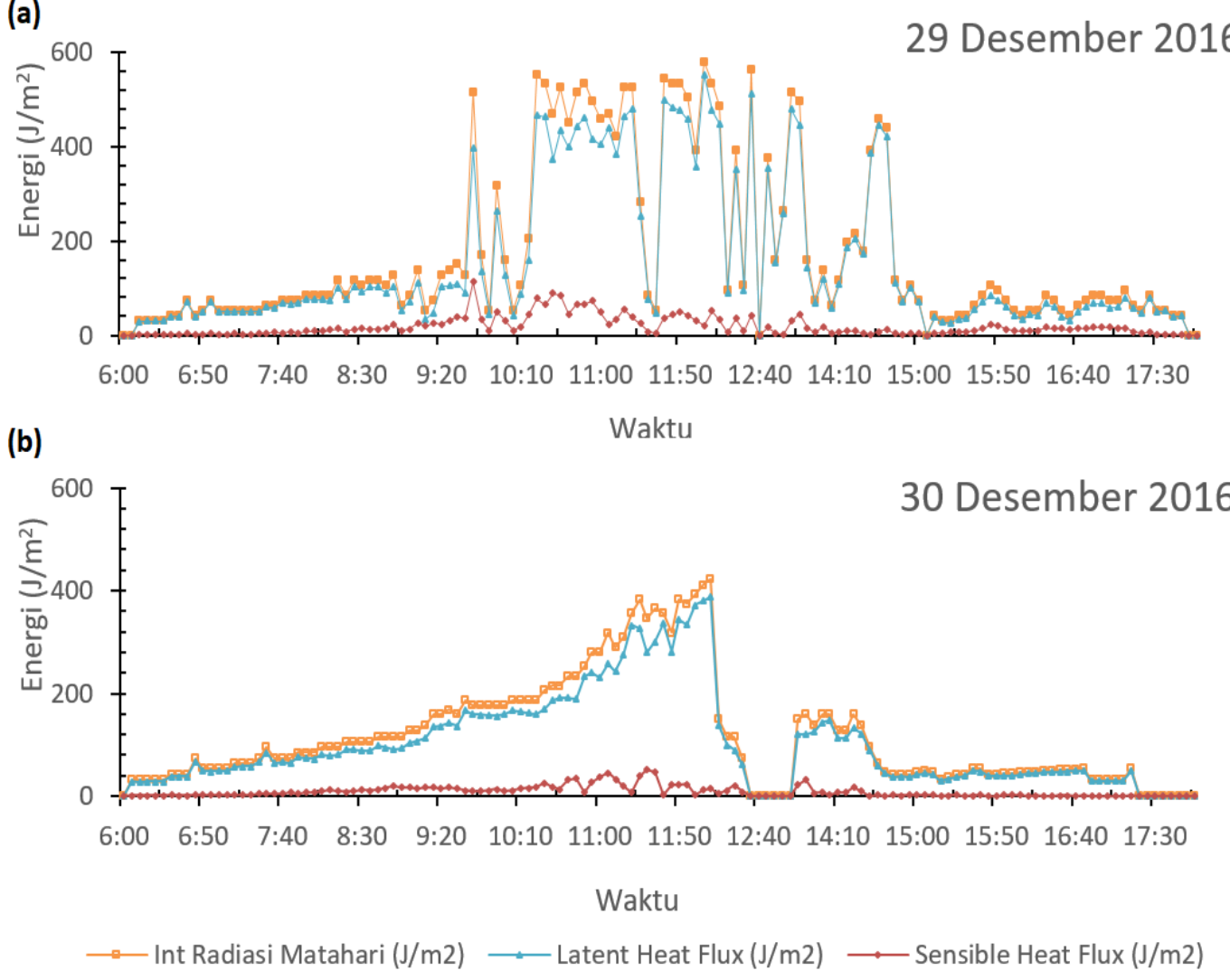

Gambar 4 Sebaran neraca energi oleh daun tanaman secara diurnal tanggal 29 Desember 2016 (a) dan 30 Desember 2016 (b) pada perlakuan N0\%M0.

Terlihat pada pukul 11:50 hingga 16:50 WIB tanggal 4 dan 5 Januari 2017 energi lebih banyak dikonversi ke dalam bentuk $\mathrm{H}_{\llcorner}$. Hal ini menjelaskan bahwa tanaman lebih butuh menguapkan air sebagai respon tanaman ke lingkungan. Tanaman menjaga suhu pada daun tetap stabil pada kondisi pertumbuhan yang optimal, dengan cara menguapkan air melalui stomata sehingga daun tidak terlalu kering.

\section{Analisis Model Pertumbuhan Biomassa}

Daun merupakan bagian penting pada tanaman dalam proses fotosintesis karena daun berfungsi untuk mengintersepsi radiasi matahari. Jumlah energi yang diintersepsi bergantung pada indeks luas daun. Tumbuhan yang memperoleh periode penyinaran pendek dan intensitas cahaya yang rendah, akan menyebabkan penyediaan hasil materi kasar dari fotosintesis berkurang. Semakin banyak tanaman menyerap energi dari daun semakin optimal tanaman melakukan fotosintesis karena energi yang tersedia oleh tanaman tercukupi.
Pertumbuhan biomassa sangat bergantung pada radiasi matahari. Pada perlakuan N0\%MO lebih banyak menyerap energi (Gambar 4) daripada perlakuan N50\%M0 (Gambar 5) sehingga pertumbuhan biomassa lebih optimal pada N0\%M0. Pada saat radiasi matahari maksimum, energi yang tercatat pada perlakuan N0\%M0 rata-rata di atas $400 \mathrm{~J} / \mathrm{m}^{2}$ (Gambar 5), dan energi yang tercatat pada perlakuan N50\%M0 rata-rata di bawah $250 \mathrm{~J} / \mathrm{m}^{2}$ (Gambar 6). Hal ini menyebabkan pertumbuhan biomassa tanaman kedelai N0\%M0 lebih baik dengan perbandingan biomassa hampir dua kali lipat dari N50\%M0 (Gambar 8b) pada 12 minggu setelah tanam (MST).

Berdasarkan konsep neraca energi daun tanaman, selain digunakan sebagai energi yang digunakan untuk fotosintesis, radiasi intersepsi juga berupa panas terasa pada permukaan daun $(\mathrm{H})$ dan energi panas untuk evapotranspirasi daun tanaman $\left(\mathrm{H}_{\mathrm{L}}\right)$. Neraca energi daun tanaman terdiri dari sensible heat flux $(\mathrm{H})$, dan latent heat flux $\left(\mathrm{H}_{\mathrm{L}}\right)$. Energi harian yang dikonversi menjadi energi $\mathrm{H}$ (Gambar 6) stabil dalam 90 HST pada perlakuan 
N0\%M0. Energi yang diintersepsi oleh daun tanaman banyak dikonversi ke energi $\mathrm{H}_{\llcorner}$. Nilai $\mathrm{H}_{\mathrm{L}}$ cendurung lebih besar pada 28 HST yang berada pada rentang nilai 6 hingga $7 \mathrm{MJ} / \mathrm{m}^{2}$. Saat umur tanaman dalam kondisi yang optimal pada $60 \mathrm{HST}$, nilai $\mathrm{H}_{\mathrm{L}}$ mengalami penurunan dan stabil pada nilai $2 \mathrm{MJ} / \mathrm{m}^{2}$, dan kembali naik menjelang panen dengan nilai $\mathrm{H}$ berada pada rentang nilai 4 hingga $8 \mathrm{MJ} / \mathrm{m}^{2}$. Nilai $\mathrm{H}_{L}$ yang relatif besar sehingga tanaman kedelai pada perlakuan N0\%MO banyak melakukan penguapan air sebagai bentuk respon tanaman terhadapat lingkungan. Nilai $H_{L}$ yang relatif besar mengakibatkan $\mathrm{T}$ bertambah tinggi dan $\mathrm{RH}$ berkurang.
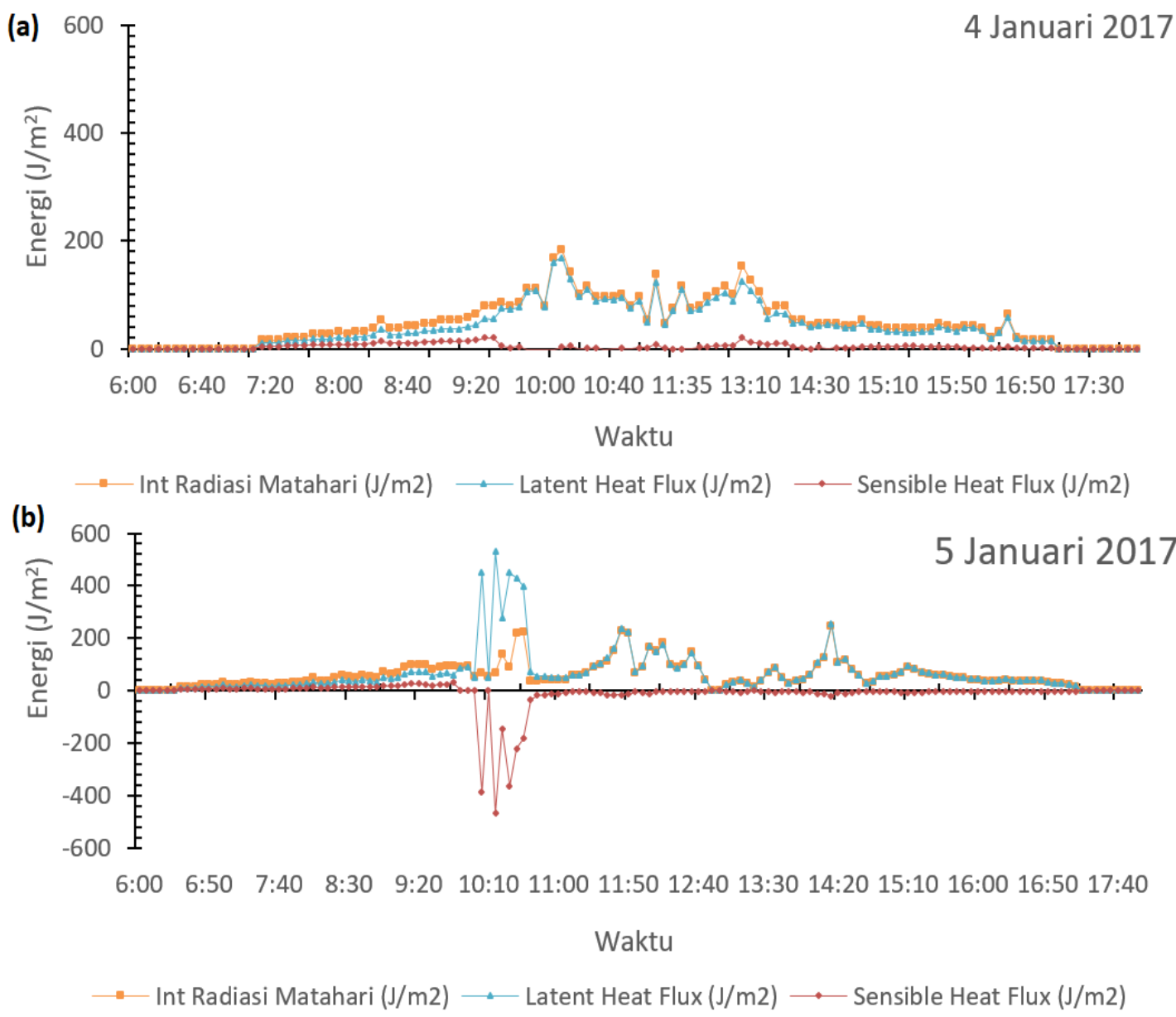

Gambar 5 Sebaran neraca energi oleh daun tanaman secara diurnal tanggal 4 Januari 2017

(a) dan 5 Januari 2017 (b) pada perlakuan N50\%M0.

Energi yang diserap oleh tanaman di lahan ternaungi $50 \%$ jauh lebih kecil dibandingkan energi yang diserap oleh tanaman tanpa naungan (Gambar 4). Tanaman kedelai perlakuan N50\%M0 memerlukan energi lebih yang diserap sebelumnya dalam berfotosintesis, sehingga hasil yang maksimal bisa tercapai pada pertumbuhan biomassa tanaman ternaungi 50\%. Terlihat pada Gambar 5 dan 6 menunjukkan semakin banyak energi yang diserap membuat pertumbuhan biomassa semakin besar.
Energi harian yang dikonversi menjadi energi $\mathrm{H}$ (Gambar 7) mengalami fluktuatif dalam 90 HST (hari setelah tanam) pada perlakuan N50\%M0. Pada tiga minggu awal pertumbuhan biomassa tanaman kedelai energi $\mathrm{H}$ mengalami peningkatan dari 0.2 sampai dengan $0.6 \mathrm{MJ} / \mathrm{m}^{2}$. Hal ini menjelaskan tanaman masih muda, dengan jumlah rumput yang masih sedikit dan jarak tanaman masih renggang, sehingga radiasi langsung mengenai permukaan tanah mengakibatkan suhu menjadi lebih hangat. 


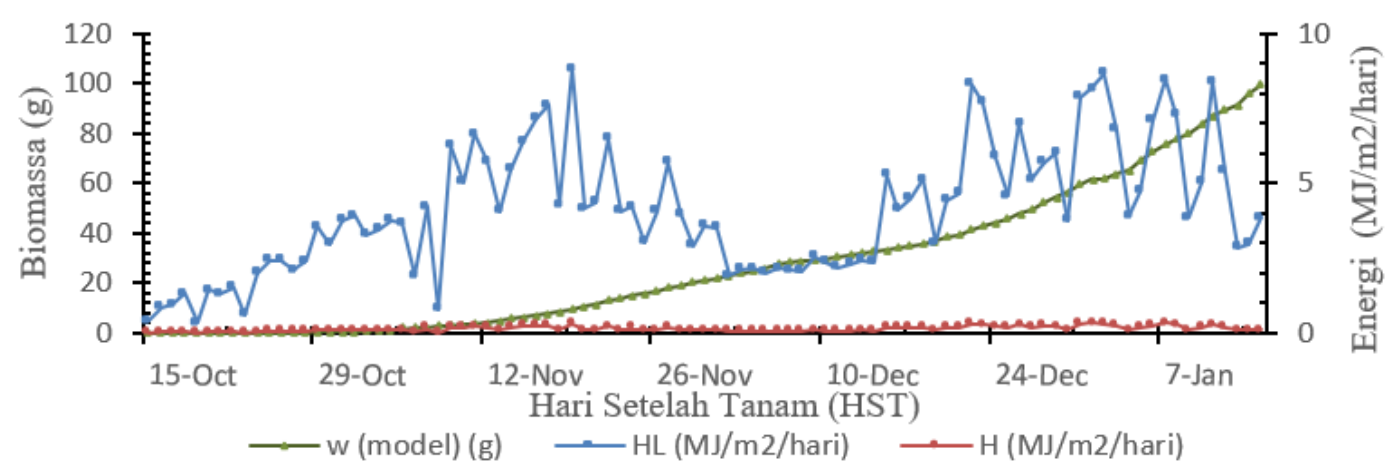

Gambar 6 Perbandingan nilai $\mathrm{H}$ dan $\mathrm{HL}$ harian pada pertumbuhan biomassa model simulasi tanaman kedelai perlakuan N0\%M0 atau tanpa naungan

Tanaman mulai tumbuh pada keadaan maksimal pada rentang tanggal 26 November hingga 15 Desember 2016 nilai $\mathrm{H}$ menurun stabil pada nilai 0.3 $\mathrm{MJ} / \mathrm{m}^{2}$ karena tajuk lebih banyak menggunakan energi untuk melakukan penguapan. Nilai $\mathrm{H}$ meningkat stabil pada nilai $1.4 \mathrm{MJ} / \mathrm{m}^{2}$ pada saat menjelang panen.

Penggunaan energi $\mathrm{H}_{\mathrm{L}}$ di lahan N50\%M0 saling berkaitan dengan energi $\mathrm{H}$ (Gambar 7). Tanaman melakukan penguapan dimanfaatkan juga untuk melepas panas lebih banyak lingkungan. Hal ini berbanding terbalik pada perlakuan NO\%M0 yang lebih banyak mengkonversi energi $\mathrm{H}_{\mathrm{L}}$ dibandingkan dengan energi $\mathrm{H}$. Naungan atau paranet yang menutupi lahan kedelai N50\%M0 menyebabkan panas terperangkap lebih banyak, sehingga lingkungan N50\%M0 lebih lembab dibandingkan dengan NO\%MO.

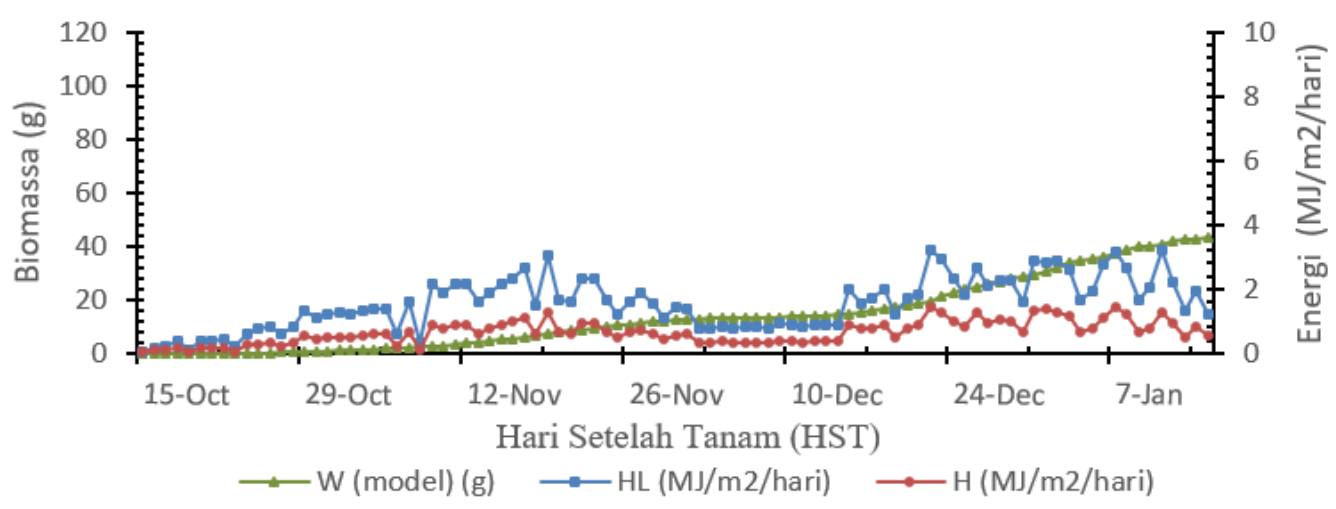

Gambar 7 Perbandingan nilai H dan HL harian pada pertumbuhan biomassa model simulasi tanaman kedelai perlakuan N50\% atau ternaungi $50 \%$.

\section{Validasi Model Simulasi}

Validasi model simulasi tanaman kedelai dalam menduga pertumbuhan biomassa dilakukan dengan uji plot 1:1 (Gambar 8). Perbandingan data pertumbuhan biomassa dilakukan dari MST ke-1 hingga ke-12. Uji plot 1:1 dilakukan dengan membandingkan hasil data observasi dan data model simulasi.

Hasil analisis plot perbandingan biomassa hasil simulasi dengan observasi (Gambar 8) menunjukkan pola pertumbuhan biomassa model memiliki pola yang sama dengan biomassa observasi pada kedua perlakuan. Uji t berpasangan antara hasil model dan hasil observasi perlakuan N0\%M0 menunjukkan hasil pengujian yang tidak berbeda nyata $(P>0.05)$ dengan $P$-Value 0.72 . Uji t berpasangan juga dilakukan antara hasil model dan hasil observasi perlakuan N50\%M0 menunjukkan hasil pengujian yang berbeda nyata $(P<0.05)$ dengan $P$-Value 0.01 . Hal ini menjelaskan bahwa hasil pertumbuhan biomassa perlakuan $\mathrm{N} 50 \% \mathrm{M} 0$ hanya mengikuti pola hasil pertumbuhan model, tetapi nilai untuk MST 5 hingga 12 selalu under estimated atau di bawah perkiraan. Jadi, model pertumbuhan biomassa pendekatan neraca energi daun tanaman pada perlakuan N0\%M0 dapat memprediksi dengan baik. 

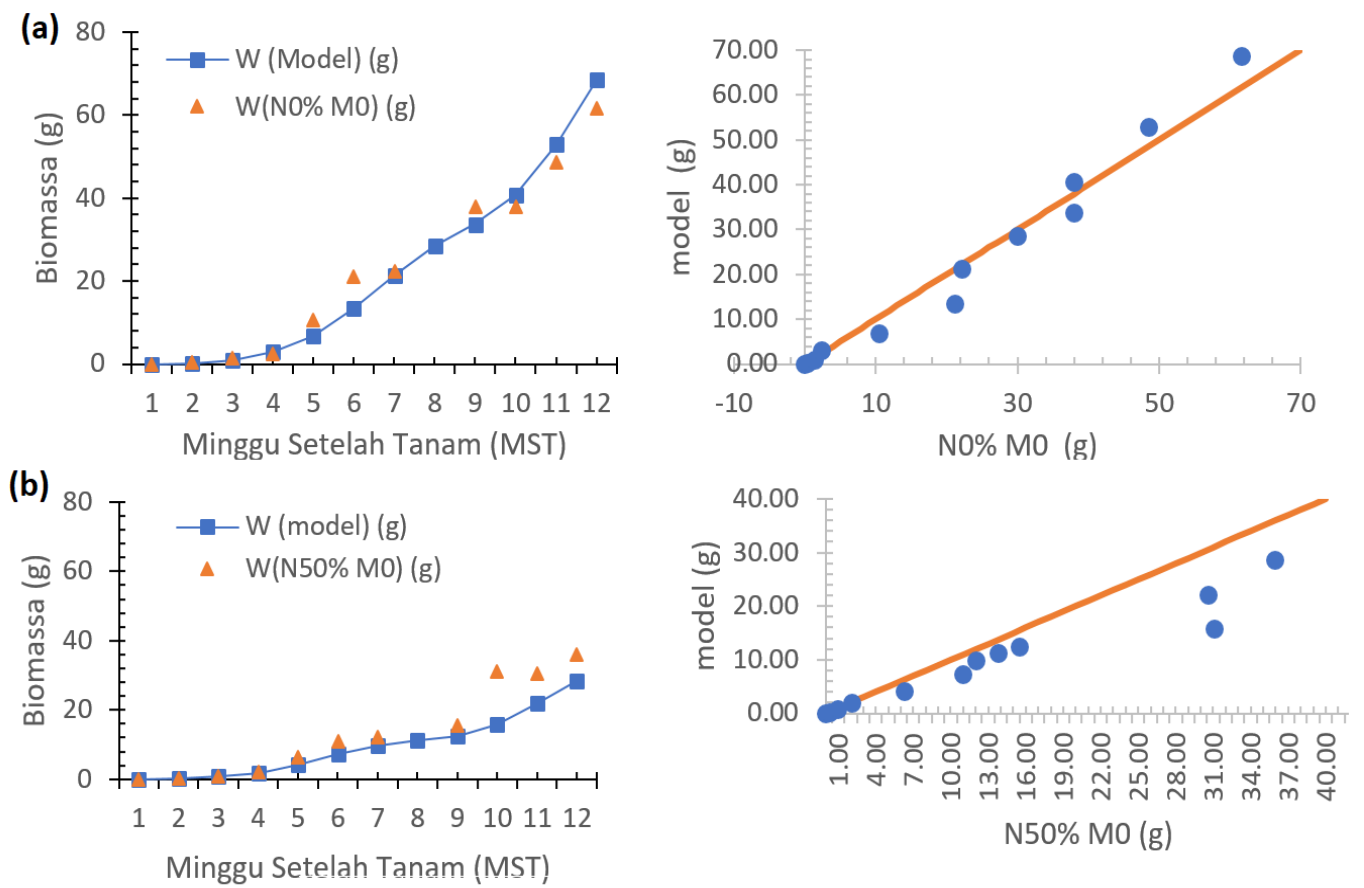

Gambar 8 Perbandingan pertumbuhan biomassa dan uji plot 1:1 hasil model simulasi dengan hasil perlakuan (a) N0\%M0, dan (b) N50\%M0.

\section{KESIMPULAN}

Tanaman kedelai memanfaatkan energi $\mathrm{H}$ (sensible heat flux) dan $\mathrm{H}_{\mathrm{L}}$ (latent heat flux) untuk memanaskan udara dan menguapkan air pada tanaman. Penggunaan energi tersebut berbeda setiap perlakuan disebabkan jumlah energi yang diintersepsi. Energi intersepsi matahari yang tercatat pada perlakuan $\mathrm{N} 0 \% \mathrm{M} 0$ rata-rata di atas $400 \mathrm{~J} / \mathrm{m}^{2}$, dan pada perlakuan N50\%M0 rata-rata dibawah $250 \mathrm{~J} / \mathrm{m}^{2}$. Pertumbuhan biomassa tanaman kedelai pada 12 MST untuk perlakuan N0\%M0 menghasilkan berat 61 gram, sedangkan perlakuan N50\%M0 36 gram. Hal ini membuktikan semakin banyak energi yang diintersepsi oleh daun tanaman semakin besar pertumbuhan biomassa tanaman.

Hubungan antara hasil model dan hasil observasi berdasarkan uji plot 1:1, menunjukkan hasil simulasi biomassa pada perlakuan N0\%M0 mendekati garis plot $1: 1$, sedangkan hasil simulasi pada perlakuan N50\%M0 cenderung berada di bawah garis plot 1:1 (under estimated). Hasil uji t berpasangan antara hasil model dan hasil observasi pada perlakuan N0\%M0 menunjukkan hasil yang tidak berbeda nyata $(P>0.05)$ dengan $P$-Value 0.72, sedangkan pada perlakuan N50\%M0 menunjukkan hasil yang berbeda nyata $(\mathrm{P}<0.05)$ dengan $P$-Value 0.01. Jadi, model pertumbuhan biomassa pendekatan neraca energi daun tanaman lebih baik memprediksi pertumbuhan biomassa tanaman kedelai N0\%M0.

\section{DAFTAR PUSTAKA}

Allen, R.G., Pereira, L.S., Raes, D., Smith, M., 1998. Crop evapotranspiration - Guidelines for computing crop water requirements - FAO Irrigation and drainage paper 56 .

Arya, S., 1988. Introduction of Micrometeorology, Second. ed, International Geophysics Series. Academic Press, San Diego.

Boote, K.J., JONES, J.W., WHITE, J.W., ASSENG, S., LIZASO, J.I., 2013. Putting mechanisms into crop production models. Plant, Cell \& Environment 36, 1658-1672. https://doi.org/10.1111/pce.12119

Chuine, I., de Cortazar-Atauri, I.G., Kramer, K., Hänninen, H., 2013. Plant Development Models, in: Schwartz, M.D. (Ed.), Phenology: An Integrative Environmental Science. Springer Netherlands, Dordrecht, pp. 275-293. https://doi.org/10.1007/978-94-007-6925-0_15

Craufurd, P.Q., Vadez, V., Jagadish, S.V.K., Prasad, P.V.V., Zaman-Allah, M., 2013. Crop science experiments designed to inform crop modeling. Agricultural and Forest Meteorology 170, 8-18. 
https://doi.org/10.1016/j.agrformet.2011.09.003

Dong, S.X., Davies, S.J., Ashton, P.S., Bunyavejchewin, S., Supardi, M.N.N., Kassim, A.R., Tan, S., Moorcroft, P.R., 2012. Variability in solar radiation and temperature explains observed patterns and trends in tree growth rates across four tropical forests. Proc Biol Sci. https://doi.org/10.1098/rspb.2012.1124

Foken, T., 2008. Micrometeorology. Springer, Berlin, Heidelberg.

García-Vila, M., Fereres, E., 2012. Combining the simulation crop model AquaCrop with an economic model for the optimization of irrigation management at farm level. European Journal of Agronomy 36, 21-31. https://doi.org/10.1016/j.eja.2011.08.003

Ghasemi, A., Zahediasl, S., 2012. Normality tests for statistical analysis: a guide for non-statisticians. International journal of endocrinology and metabolism 10, 486-489. https://doi.org/10.5812/ijem.3505

Gutschick, V.P., 2016. Leaf Energy Balance: Basics, and Modeling from Leaves to Canopies, in: Hikosaka, K., Niinemets, Ü., Anten, N.P.R. (Eds.), Canopy Photosynthesis: From Basics to Applications. Springer Netherlands, Dordrecht, pp. 23-58. https://doi.org/10.1007/978-94-017-7291-4_2

Hammer, G., McLean, G., Doherty, A., van Oosterom, E., Chapman, S., 2016. Sorghum Crop Modeling and Its Utility in Agronomy and Breeding, in: Sorghum: State of the Art and Future Perspectives, Agronomy Monographs. American Society of Agronomy and Crop Science Society of America, Inc., Madison, WI. https://doi.org/10.2134/agronmonogr58.2014.00 64

Handoko, 1994. Dasar Penyusunan dan Aplikasi Model Simulasi Komputer untuk Pertanian. Jurusan Geofisika dan Meteorologi, FMIPA-IPB, Bogor.

Hatfield, J.L., Prueger, J.H., 2015. Temperature extremes: Effect on plant growth and development. Weather and Climate Extremes 10, 4-10. https://doi.org/10.1016/j.wace.2015.08.001

Kaufman, M., Marsh, W., 2013. Physical Geography: Great Systems and Global Environtment. Cambrigde University Press, New York.
Kloss, S., Pushpalatha, R., Kamoyo, K.J., Schütze, N., 2012. Evaluation of Crop Models for Simulating and Optimizing Deficit Irrigation Systems in Arid and Semi-arid Countries Under Climate Variability. Water Resources Management 26, 997-1014. https://doi.org/10.1007/s11269-011-9906-y

Poorter, H., Jagodzinski, A.M., Ruiz-Peinado, R., Kuyah, S., Luo, Y., Oleksyn, J., Usoltsev, V.A., Buckley, T.N., Reich, P.B., Sack, L., 2015. How does biomass distribution change with size and differ among species? An analysis for 1200 plant species from five continents. New Phytologist 208, 736-749. https://doi.org/10.1111/nph.13571

Rauff, K.O., Bello, R., 2015. A Review of Crop Growth Simulation Models as Tools for Agricultural Meteorology. Agricultural Sciences 06, 1098-1105. https://doi.org/10.4236/as.2015.69105

Sheehy, J., Mitchell, P., 2013. Designing rice for the 21st century: the three laws of maximum yield, Discussion Paper. IRRI, Los Banos.

Singels, A., 2013. Crop Models, in: Sugarcane: Physiology, Biochemistry, and Functional Biology. John Wiley \& Sons, Ltd, pp. 541-577. https://doi.org/10.1002/9781118771280.ch20

Song, X., BARBOUR, M.M., FARQUHAR, G.D., VANN, D.R., HELLIKER, B.R., 2013. Transpiration rate relates to within- and across-species variations in effective path length in a leaf water model of oxygen isotope enrichment. Plant, Cell \& Environment 36, 1338-1351. https://doi.org/10.1111/pce.12063

Tilly, N., Hoffmeister, D., Cao, Q., Huang, S., LenzWiedemann, V., Miao, Y., Bareth, G., 2014. Multitemporal crop surface models: accurate plant height measurement and biomass estimation with terrestrial laser scanning in paddy rice. Journal of Applied Remote Sensing 8, 1-24.

Van Roekel, R.J., Purcell, L.C., 2014. Soybean Biomass and Nitrogen Accumulation Rates and Radiation Use Efficiency in a Maximum Yield Environment. Crop Science 54, 1189-1196. https://doi.org/10.2135/cropsci2013.08.0546

Ye, H., Yuan, Z., Zhang, S., 2013. The Heat and Mass Transfer Analysis of a Leaf. Journal of Bionic Engineering 10, 170-176. https://doi.org/10.1016/S1672-6529(13)60212-7 